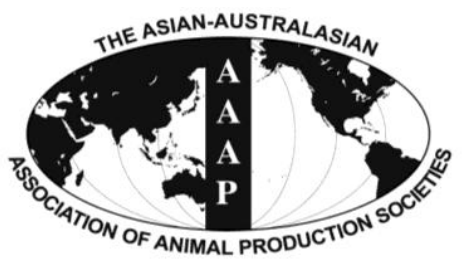

Asian-Aust. J. Anim. Sci.

Vol. 25, No. $10: 1395-1403$

October 2012

www.ajas.info

http://dx.doi.org/10.5713/ajas.2012.12281

\title{
Chemical Composition, In vitro Gas Production, Ruminal Fermentation and Degradation Patterns of Diets by Grazing Steers in Native Range of North Mexico
}

\author{
M. Murillo*, E. Herrera ${ }^{1}$, F. O. Carrete ${ }^{1}$, O. Ruiz $^{2}$ and J. S. Serrato ${ }^{3}$ \\ Faculty of Veterinary Medicine and Animal Science, Juárez University of the State of Durango, \\ Carretera Durango-Mezquital, Km. 11.5, CP, 34620, Durango, Mexico
}

\begin{abstract}
The objective of the study was to quantify annual and seasonal differences in the chemical composition, in vitro gas production, in situ degradability and ruminal fermentation of grazing steers' diets. Diet samples were collected with four esophageal cannulated steers $(350 \pm 3 \mathrm{~kg} \mathrm{BW})$; and four ruminally cannulated heifers $(342 \pm 1.5 \mathrm{~kg} \mathrm{BW})$ were used to study the dry matter degradation and fermentation in rumen. Data were analyzed with repeated measurements split plot design. The crude protein, in vitro dry matter digestibility and metabolizable energy were higher during the first year of trial and in the summer $(\mathrm{p}<0.01)$. The values of calcium, phosphorus, magnesium, zinc and copper were higher in summer $(\mathrm{p}<0.05)$. The gas produced by the soluble and insoluble fractions, as well as the constant rate of gas production were greater in summer and fall $(\mathrm{p}<0.01)$. The ammonia nitrogen $\left(\mathrm{NH}_{3} \mathrm{~N}\right)$ and total volatile fatty acids concentrations in rumen, the soluble and degradable fractions, the constant rate of degradation and the effective degradability of DM and NDF were affected by year $(p<0.05)$ and season $(p<0.01)$. Our study provides new and useful knowledge for the formulation of protein, energetic and mineral supplements that grazing cattle need to improve their productive and reproductive performance. (Key Words: Rangelands, Minerals, In situ Degradation, In vitro Fermentation, In vivo Fermentation)
\end{abstract}

\section{INTRODUCTION}

Some studies report that, as a result of drastic climate change, the animals in the northern region of México have periods of 90 to $100 \mathrm{~d}$ of favorable grazing conditions and if the number of days is reduced, the survival of these animals may be in jeopardy (González et al., 2007). Under longterm drought conditions, the evaluation of nutritive quality of the diet selected by grazing cattle across seasons is essential to design strategic programs of dietary supplementation. However, these evaluations may be complemented with studies of digestion and ruminal fermentation and minerals content, to more precisely

\footnotetext{
* Corresponding Author: Manuel Murillo Ortiz. Tel: +52-1-6188262996, Fax: +52-1-618-8100703, E-mail: muom8@yahoo.com.mx

${ }^{1}$ Faculty of Veterinary Medicine and Animal Science, Juárez University of the State of Durango, México.

${ }^{2}$ Faculty of Animal Science and Ecology, Autonomous University of Chihuahua, Mexico.

${ }^{3}$ Faculty of Agriculture and Animal Science, Juárez University of the State of Durango, México.

Submitted May 22, 2012; Accepted Jul. 16, 2012; Revised Aug. 6, 2012
}

establish dietary supplementation needs. The rangelands in semiarid environments tend to vary greatly in quality and quantity of forages, which subsequently affects diet composition and selectivity of grazing cattle (Obiedat et al., 2002). These changes may be accompanied by decreases in chemical composition, ruminal ammonia $\left(\mathrm{NH}_{3} \mathrm{~N}\right)$ and total volatile fatty acid (VFA) concentrations. The disappearance of digesta from the gastrointestinal tract in ruminants is a function of the competing processes of ruminal digestion and passage of undigested residues (Van Soest, 1994). Studies directed toward evaluation of rates of passage and ruminal degradability in ruminants grazing native rangelands should provide insight into the mechanism controlling voluntary intake in such animals (McCollum et al., 1985). Ruminal degradability has been used often to estimate nutritive quality of different grass species (Murillo et al., 2003; Jancík, 2010). Determination of in vitro gas production also provides information on fermentation kinetics of the forage consumed by ruminants. The in vitro gas production has been widely used to estimate the nutritive quality of different classes of forages (Njidda, 2010). Grazing beef cattle also require a number of minerals 
for optimal growth and reproduction. According to McDowell (1992) the most critical minerals for grazing cattle are: $\mathrm{Ca}, \mathrm{P}, \mathrm{Na}, \mathrm{Co}, \mathrm{Cu}, \mathrm{Se}$ and $\mathrm{Zn}$. During disease status mineral requirements of cattle may be affected by immune system response. High concentrations of $\mathrm{Zn}$ have been shown to be beneficial to the ruminant's health during disease; and $\mathrm{Zn}, \mathrm{Cu}$, Se and Iron seem to be necessary for inmunocompetence (NRC, 2000). Knowledge of mineral content of the diet selected by grazing cattle is necessary in order to design supplementation strategies under range conditions. Although the chemical composition of the diet in grazing cattle is widely known, there is very little information about mineral content, in situ degradability and rumen fermentation in vitro and in vivo of the diet consumed by grazing cattle in native rangelands. This study was conducted to determine and compare, seasonally, across two consecutive years, the chemical composition, in vitro gas production and ruminal fermentation and degradation patterns of diets consumed by grazing steers.

\section{MATERIAL AND METHODS}

\section{Area of the study and climatic conditions}

The study was carried out during two consecutive years (2004 and 2005) in a medium-sized shrub-grassland located at the east of the city of Durango, Mexico $\left(24^{\circ} 22^{\prime} \mathrm{N}, 104^{\circ}\right.$ $32^{\prime} \mathrm{W}$ ), at an altitude of about $1938 \mathrm{~m}$ above sea, which has a dry temperate $\left(\mathrm{BS}_{1} \mathrm{k}\right)$ climate with average annual temperature and rainfall of $17.5^{\circ} \mathrm{C}$ and $450 \mathrm{~mm}$, respectively. Rainfall in 2004 was $547.5 \mathrm{~mm}$, and 2005 was drier than normal with $238.0 \mathrm{~mm}$. The study area covers 2,000 ha (6 ha/AU) with an average of forage biomass of $1,796 \mathrm{~kg}$ of DM/ha. During the two years of the study, the vegetation cover was estimated by using minimum area sampling with nested points. Dominant grass species included Melinis repens Willd (rose natal grass), Chloris virgata (feather fingergrass), Bouteloua gracilis (blue grama), Aristida adscensionis (sixweeks threeawn) and Andropogon barbinodis (cane bluestem); bushes: Acacia tortuosa (poponax), Prosopis juliflora (mezquite), Opuntia spp (prickly pears and chollas), Mimosa biuncifera (cat claw); plus a wide variety of annual herbs. The pasture had not been grazed the previous years and forage availability was never limiting during any of the sampling periods.

\section{Animals and sample collection periods}

After of an initial $23 \mathrm{~d}$ adaptation period of animals under study, eight sampling periods, each $11 \mathrm{~d}$ long were conducted: (1) January 2 to 12, (2) February 4 to 14, (3) April 13 to 23, (4) May 15 to 25, (5) July 20 to 30, (6) August 11 to 21, (7) October 12 to 23 and (8) November 20 to 30 . The first two collection periods were considered to be in winter; 3 and 4, spring; 5 and 6, summer; and 7 and 8, fall. During each sampling period, four steers with esophageal cannulae and four heifers with rumen cannulae grazed freely. Surgery was performed on the steers and heifers according to procedures approved by the University of Durango Laboratory Care Advisory Committee.

\section{Chemical composition}

Diet samples were collected with the esophageal cannulated steers, during the first $4 \mathrm{~d}$ of each sampling period (Holecheck et al., 1982). Collections were made at $0700 \mathrm{~h}$ when steers were grazing most intensely. Steers were fitted with screen wire bottom collection bags and allowed to graze for 30 to $45 \mathrm{~min}$ periods. The sample from each steer was drained through $40 \mathrm{~mm}$ screen to remove saliva, mixed and divided into four subsamples. The subsamples were used for the determination of chemical composition, ruminal degradability, in vitro gas production and mineral contents. Esophageal samples were dried at $60^{\circ} \mathrm{C}$ for $48 \mathrm{~h}$ and ground through a $1 \mathrm{~mm}$ screen in a Wiley mill. Dry matter (DM), CP, OM (AOAC, 1997), NDF (Van Soest et al., 1991) and IVDMD (Daisy II ANKOM Technology, Macedon NY, USA) were determined. We estimated ME content with the formulas used by Waterman et al. (2007): digestible energy $(\mathrm{DE} ; \mathrm{Mcal} / \mathrm{kg})=(0.039 \times$ $(\mathrm{OMD} \%))-0.10 ; \mathrm{ME}(\mathrm{Mcal} / \mathrm{kg})=\mathrm{DE}(\mathrm{Mcal} / \mathrm{kg}) \times 0.82$. Where: OMD is the organic matter degradability obtained after $48 \mathrm{~h}$ incubation in the rumen.

\section{Mineral content}

Esophageal samples were incinerated in a muffle oven at $600^{\circ} \mathrm{C}$ during $5 \mathrm{~h}$. The ashes obtained were digested in a solution $\mathrm{HCl}-\mathrm{HNO}_{3}$ and concentrations of $\mathrm{Ca}, \mathrm{Mg}, \mathrm{Na}, \mathrm{Cu}$ $\mathrm{Mn}, \mathrm{Zn}$, and Se were determined by atomic absorption spectrophotometry; whereas, $\mathrm{P}$ content was quantified by ultraviolet-visible spectrophotometry (Cherney, 2000).

\section{In vitro gas production}

The in vitro gas production was carried out using the method proposed by Menke and Steingass (1988). Approximately $500 \mathrm{mg}$ of sample of diet ground to $1 \mathrm{~mm}$ were placed in triplicate in $100 \mathrm{ml}$ calibrated glass syringes. Buffer and mineral solutions were added in a 2:1 ratio to rumen liquid collected from two rumen fistulated heifers fed with alfalfa hay. Forty milliliters of this mixture were introduced in each syringe for incubation. Syringes were shaken gently at each reading and the gas volume was recorded at $0,3,6,9,15,24,36,48,72$ and $96 \mathrm{~h}$ of incubation. Data obtained of gas production were adjusted at the model proposed by McDonald (1981): $\mathrm{GP}_{(t)}=a+b x$ $\left(1-\mathrm{e}^{-c(t-L)}\right)$. Where: $\mathrm{GP}_{(t)}$ is the gas produced at time $t$, ' $a$ ' is gas produced by the soluble fraction, ' $b$ ' is gas produced by 
the insoluble but slowly fermenting fraction, ' $c$ ' is constant gas production rate, ' $t$ ' is time of fermentation and ' $L$ ' is lag time.

\section{Ruminal fermentation, in situ degradability and passage rate}

At 12:00 h on d 5 and 6 of a sampling period, ruminal liquid samples were extracted from the rumen of cannulated heifers. Approximately $100 \mathrm{ml}$ of whole ruminal liquid was extracted from each heifer and the $\mathrm{pH}$ measured immediately with a combination electrode. The collected ruminal content was strained through four layers of cheesecloth and divided into two subsamples. The first subsample $(10 \mathrm{ml})$ was acidified with $0.3 \mathrm{ml}$ of $50 \% \mathrm{H}_{2} \mathrm{SO}_{4}$ and frozen immediately at $-40^{\circ} \mathrm{C}$ and later analyzed for $\mathrm{NH}_{3} \mathrm{~N}$; the second subsample, $(10 \mathrm{ml})$ was acidified with $2.5 \mathrm{ml}$ of $25 \%$ metaphosporic acid and frozen at $-40^{\circ} \mathrm{C}$ for later VFA analysis (Galyean, 1997). On days 7, 8, 9 and 10 of a sampling period, in situ degradability of the DM and NDF during grazing of ruminally cannulated heifers was determined. Duplicate polyester bags $(10 \times 20$; pore size of $50 \pm 10 \mu \mathrm{m}$; Ankom, Spencerport, NY, USA), that contained $10 \mathrm{~g}$ of sample ground to $2 \mathrm{~mm}$ were suspended in the rumen for $0,3,6,9,15,24,36,48,72,96 \mathrm{~h}$. After removal, bags were rinsed in cold tap water until effluent was clear, after which bags were dried at $60^{\circ} \mathrm{C}$ for $48 \mathrm{~h}$ in a forced-air over and weighed. We determined degradability of DM at time " 0 " by immersing the bags containing $10 \mathrm{~g}$ of sample in the rumen for $1 \mathrm{~min}$ and then washing them as described above. The residues obtained from each incubation time, were dried at $60^{\circ} \mathrm{C}$ for $48 \mathrm{~h}$ and analyzed for DM and NDF. The rumen degradation parameters of DM, and NDF were calculated using the model of Orskov and Shand (1997): $\operatorname{Deg}_{(\mathrm{t})}=a+b \times\left(1-\exp ^{-c t}\right)$. Where: $\operatorname{Deg}_{(\mathrm{t})}$ is disappearance of $\mathrm{DM}$ and NDF at time $t$; ' $a$ ' is soluble fraction of the DM and NDF at the initiation of incubation (time 0 ), ' $b$ ' is fraction of DM and NDF degradable in the rumen, ' $c$ ' is rate constant of degradation of ' $b$ ', and ' $t$ ' is time of incubation. Using parameters obtained from this model, we estimated the fractions ' $A$ ' and ' $B$ ' of NDF. The fraction ' $A$ ' represents particles of the diet that were lost as a result of washing bags (time 0 ) and ' $\mathrm{B}$ ' is the insoluble yet fermentable fraction defined as $\mathrm{B}=(\mathrm{a}+\mathrm{b})-\mathrm{A}$ (Khazaal et al., 1995). On d 11 of sampling period and before initiating grazing, we removed all ruminal content in each heifer and placed them in black polyethylene bags, weighed them, took $0.5 \mathrm{~kg}$ samples and immediately reintroduced the contents into the rumen of the heifer from which it came. Acid insoluble ash (AIA) was determined in diet sample as well as in samples of ruminal content. The ruminal passage rate $(\mathrm{Kp})$ was determined dividing AIA content in the diet by total AIA in the ruminal content (Ogden et al., 2005). At once, the effective ruminal degradability of DM (EDDM), and NDF (EDNDF) were calculated according to McDonald (1981): $\mathrm{ED}=a+b \times(c / c+k p))$. Where: $k p$ is ruminal passage rate calculated in this study.

\section{Statistical methods}

Data were analyzed as a repeated measurements design using MIXED procedure of SAS (2003). The model included effects for year, season, month and their interactions. Month was included as repeated effect, and animal within year $\times$ season was the subject for analysis. The variation between animals was specified by the RANDOM statement as animal within year $\times$ season. Individual animal was the experimental unit in all analyses. Least squares means and standard error of mean (SEM) were calculated and statistically separated by the PDIFF options of SAS (2003). Autoregressive Order 1 was used as the covariance structure, because it was better fitting structure, based on comparison of covariance structures with Akaike and Bayesian information criterions (Littell et al., 1998). The curves of in situ degradability and in vitro gas production were adjusted using NLIN procedure of SAS (2003).

\section{RESULTS AND DISCUSSION}

\section{Chemical composition}

No year $\times$ season, year $\times$ month, season $\times$ month and year $\times$ season $\times$ month interactions $(\mathrm{p}>0.05)$ were observed for $\mathrm{CP}$, NDF, IVDMD and ME values. However, the CP, NDF, IVDMD and ME values were different among years ( $\mathrm{p}<0.01$; Table 1). The NDF content was $8 \%$ higher in 2005 than in 2004, while CP content was 20\% higher in 2004. These differences in chemical composition of diets may be induced by registered rainfall in the two years of study (Cline et al., 2009). The CP, IVDMD and ME values were greater in summer and fall as compared to winter and spring $(\mathrm{p}<0.01)$; while NDF content was higher in spring and winter as compared to summer and fall $(\mathrm{p}<0.01)$. An 80 $\mathrm{g} / \mathrm{kg} \mathrm{CP}$ level is considered as an adequate forage quality for grazing ruminants (NRC, 2000). Therefore, except for spring and winter, the $\mathrm{CP}$ content can be considered to be high nutritive quality for grazing cattle. The value obtained for $\mathrm{ME}$ in the spring $(1.8 \mathrm{Mcal} / \mathrm{Kg} \mathrm{DM})$ indicated that the energy requirements for maintenance of growing beef cattle (2.0 Mcal/Kg DM; NRC, 2000) would not satisfied. Chávez and González (2009) reported that nutritive quality of the diet of grazing cattle in northern Mexico is higher in summer and fall versus winter and spring and attributing the differences to the phenology of rangelands' plants. Consequently, these variables were also higher in the months of summer (July and August) and fall (October and November) than in the months of spring (April and May) and winter (January and February) $(\mathrm{p}<0.01)$. 
Table 1. Chemical composition of the diet consumed by grazing steers

\begin{tabular}{|c|c|c|c|c|}
\hline & $\mathrm{CP}$ & $\mathrm{NDF}$ & IVDMD & \multirow{2}{*}{$\begin{array}{c}\mathrm{ME} \\
\text { Mcal/kg DM }\end{array}$} \\
\hline & \multicolumn{3}{|c|}{ - } & \\
\hline \multicolumn{5}{|l|}{ Year (Y) } \\
\hline 2004 & $117.6^{\mathrm{a}}$ & $699.3^{\mathrm{b}}$ & $642.6^{\mathrm{a}}$ & $2.3^{\mathrm{a}}$ \\
\hline 2005 & $96.2^{\mathrm{b}}$ & $756.0^{\mathrm{a}}$ & $601.0^{\mathrm{b}}$ & $1.9^{\mathrm{b}}$ \\
\hline SEM & 2.1 & 2.2 & 1.1 & 1.4 \\
\hline \multicolumn{5}{|l|}{ Season $(\mathrm{S})$} \\
\hline Spring & $54.7^{\mathrm{d}}$ & $745.3^{\mathrm{a}}$ & $565.6^{\mathrm{d}}$ & $1.8^{\mathrm{c}}$ \\
\hline Summer & $127.2^{\mathrm{a}}$ & $670.6^{\mathrm{d}}$ & $664.7^{\mathrm{a}}$ & $2.4^{\mathrm{a}}$ \\
\hline Fall & $112.1^{\mathrm{b}}$ & $693.0^{\mathrm{c}}$ & $619.6^{\mathrm{b}}$ & $2.3^{\mathrm{a}}$ \\
\hline Winter & $62.6^{\mathrm{c}}$ & $737.2^{\mathrm{b}}$ & $581.6^{\mathrm{c}}$ & $2.0^{\mathrm{b}}$ \\
\hline SEM & 1.6 & 2.1 & 1.3 & 1.1 \\
\hline \multicolumn{5}{|l|}{ Month (M) } \\
\hline January & $64.2^{\mathrm{e}}$ & $739.2^{\mathrm{c}}$ & $574.3^{\mathrm{e}}$ & $2.0^{\mathrm{c}}$ \\
\hline Febraury & $61.1^{\mathrm{f}}$ & $735.3^{\mathrm{d}}$ & $589.0^{\mathrm{f}}$ & $2.0^{\mathrm{c}}$ \\
\hline April & $56.4^{\mathrm{g}}$ & $744.5^{\mathrm{b}}$ & $568.0^{\mathrm{g}}$ & $1.9^{\mathrm{c}}$ \\
\hline May & $53.0^{\mathrm{h}}$ & $746.1^{\mathrm{a}}$ & $563.3^{\mathrm{h}}$ & $1.8^{\mathrm{c}}$ \\
\hline July & $126.1^{\mathrm{b}}$ & $673.0^{\mathrm{g}}$ & $663.7^{\mathrm{b}}$ & $2.3^{\mathrm{b}}$ \\
\hline August & $128.4^{\mathrm{a}}$ & $668.3^{\mathrm{h}}$ & $665.8^{\mathrm{a}}$ & $2.5^{\mathrm{a}}$ \\
\hline October & $113.0^{\mathrm{c}}$ & $687.8^{\mathrm{f}}$ & $621.0^{\mathrm{c}}$ & $2.3^{\mathrm{b}}$ \\
\hline November & $111.3^{\mathrm{d}}$ & $698.3^{\mathrm{e}}$ & $618.2^{\mathrm{d}}$ & $2.2^{\mathrm{b}}$ \\
\hline SEM & 2.3 & 1.6 & 1.2 & 1.8 \\
\hline Effects & $\mathrm{p}<$ & $\mathrm{p}<$ & $\mathrm{p}<$ & $\mathrm{p}<$ \\
\hline $\mathrm{Y}$ & $* *$ & $* *$ & $* *$ & $* *$ \\
\hline $\mathrm{S}$ & $* *$ & $* *$ & $* *$ & $* *$ \\
\hline M & $* *$ & $* *$ & $* *$ & $* *$ \\
\hline
\end{tabular}

abcdefgh Means with different superscripts, within column, are different. SEM $=$ Standard error of mean. $* * \mathrm{p}<0.01$.

\section{Mineral content}

The mineral content of diet is shown in Table 2. No year $\times$ season, year $\times$ month, season $\times$ month and year $\times$ season $\times$ month interactions were observed for the macro and trace mineral evaluated in this study $(p>0.05)$. However, the values of $\mathrm{Ca}, \mathrm{P}, \mathrm{Mg}, \mathrm{Na}, \mathrm{Zn}$, and $\mathrm{Cu}$ were greater in 2004 versus 2005 ( $\mathrm{p}<0.05$ ). Similarly, the $\mathrm{Ca}, \mathrm{P}, \mathrm{Mg}, \mathrm{Na}, \mathrm{Zn}$, and $\mathrm{Cu}$ content of diet selected was higher in summer compared to winter and spring $(\mathrm{p}<0.05)$. Overall, the $\mathrm{Ca}, \mathrm{P}, \mathrm{Mg}, \mathrm{Na}$, $\mathrm{Zn}$ and $\mathrm{Cu}$ content were higher in August; and lowest in May ( $\mathrm{p}<0.05)$. Nevertheless, Se value was greater in 2005 than $2004(\mathrm{p}<0.05)$ and higher in spring as compared with summer, fall and winter $(\mathrm{p}<0.05)$. With the exception of $P$, the diet consumed for cattle throughout the years, seasons and months had appropriate amounts of $\mathrm{Ca}, \mathrm{Na}, \mathrm{Mg}, \mathrm{Zn}$, Se, and $\mathrm{Co}$ to meet requirements of beef cattle grazing native rangelands. Under conditions similar to those of our study, Arthington and Swenson (2004) found differences between seasons in contents of $\mathrm{Ca}, \mathrm{P}, \mathrm{Na}, \mathrm{Mg}, \mathrm{Zn}$, and $\mathrm{Cu}$. According to McDowell (2003) and Haenlein and Ramirez (2007) these differences in the mineral content of diets may be attributed to the interaction of a number of factors including soil, plant species, yield, pasture management, climate (temperature and rainfall) and stages of maturity. A sizable amount on the total $\mathrm{Ca}, \mathrm{Cu}$ and $\mathrm{Zn}$ is associated with the NDF fraction (Van Soest, 1994). The association of certain minerals with fiber or other insoluble plant components could also decrease the rate and extent of

Table 2. Mineral content of the diet consumed by grazing steers

\begin{tabular}{|c|c|c|c|c|c|c|c|}
\hline & $\mathrm{Ca}$ & $\mathrm{P}$ & $\mathrm{Mg}$ & $\mathrm{Na}$ & $\mathrm{Zn}$ & $\mathrm{Se}$ & $\mathrm{Cu}$ \\
\hline & \multicolumn{4}{|c|}{ 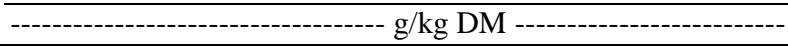 } & \multicolumn{3}{|c|}{ 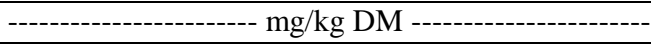 } \\
\hline \multicolumn{8}{|c|}{ (2) } \\
\hline 2004 & $5.8^{\mathrm{a}}$ & $1.3^{\mathrm{a}}$ & $3.6^{\mathrm{a}}$ & $1.5^{\mathrm{a}}$ & $36.7^{\mathrm{a}}$ & $0.82^{\mathrm{b}}$ & $13^{\mathrm{a}}$ \\
\hline 2005 & $4.7^{\mathrm{b}}$ & $1.1^{\mathrm{a}}$ & $2.6^{\mathrm{b}}$ & $1.3^{\mathrm{a}}$ & $32.2^{\mathrm{b}}$ & $0.93^{\mathrm{a}}$ & $12^{\mathrm{b}}$ \\
\hline SEM & 1.63 & 0.16 & 0.80 & 0.028 & 5.4 & 0.09 & 4.6 \\
\hline \multicolumn{8}{|l|}{ Season (S) } \\
\hline Spring & $4.2^{\mathrm{b}}$ & $1.1^{\mathrm{b}}$ & $2.1^{\mathrm{b}}$ & $1.1^{\mathrm{c}}$ & $31.9^{c}$ & $0.96^{\mathrm{a}}$ & $10^{\mathrm{b}}$ \\
\hline Summer & $6.4^{\mathrm{a}}$ & $1.4^{\mathrm{a}}$ & $3.8^{\mathrm{a}}$ & $1.8^{\mathrm{a}}$ & $39.0^{\mathrm{a}}$ & $0.58^{\mathrm{d}}$ & $15^{\mathrm{a}}$ \\
\hline Fall & $5.6^{\mathrm{a}}$ & $1.2^{\mathrm{ab}}$ & $3.5^{\mathrm{a}}$ & $1.5^{\mathrm{ab}}$ & $36.0^{\mathrm{ab}}$ & $0.70^{\mathrm{c}}$ & $14^{\mathrm{a}}$ \\
\hline Winter & $4.7^{\mathrm{a}}$ & $1.2^{\mathrm{ab}}$ & $2.6^{\mathrm{b}}$ & $1.3^{\mathrm{bc}}$ & $34.1^{\mathrm{bc}}$ & $0.86^{\mathrm{b}}$ & $10^{\mathrm{b}}$ \\
\hline SEM & 1.64 & 0.58 & 0.41 & 0.010 & 4.3 & 0.10 & 3.77 \\
\hline \multicolumn{8}{|l|}{ Month (M) } \\
\hline January & $4.8^{\mathrm{d}}$ & $1.3^{\mathrm{bc}}$ & $2.7^{\mathrm{c}}$ & $1.4^{\mathrm{bc}}$ & $34.6^{\mathrm{c}}$ & $0.88^{\mathrm{b}}$ & $12^{\mathrm{c}}$ \\
\hline February & $4.6^{\mathrm{de}}$ & $1.2^{\mathrm{bc}}$ & $2.5^{\mathrm{cd}}$ & $1.2^{\mathrm{cd}}$ & $33.7^{\mathrm{c}}$ & $0.84^{\mathrm{b}}$ & $11^{\mathrm{cd}}$ \\
\hline April & $4.3^{\mathrm{eh}}$ & $1.2^{\mathrm{bc}}$ & $2.2^{\mathrm{de}}$ & $1.2^{\mathrm{cd}}$ & $32.6^{\mathrm{cd}}$ & $0.95^{\mathrm{a}}$ & $10^{\mathrm{d}}$ \\
\hline May & $4.1^{\mathrm{h}}$ & $1.1^{\mathrm{c}}$ & $2.1^{\mathrm{e}}$ & $1.1^{\mathrm{d}}$ & $31.2^{\mathrm{d}}$ & $0.97^{\mathrm{a}}$ & $10^{\mathrm{d}}$ \\
\hline July & $6.3^{\mathrm{ab}}$ & $1.4^{\mathrm{ab}}$ & $3.7^{\mathrm{a}}$ & $1.7^{\mathrm{ab}}$ & $38.3^{\mathrm{a}}$ & $0.61^{\mathrm{d}}$ & $14^{b}$ \\
\hline August & $6.6^{\mathrm{a}}$ & $1.5^{\mathrm{a}}$ & $3.9^{\mathrm{a}}$ & $1.9^{\mathrm{a}}$ & $39.7^{\mathrm{a}}$ & $0.55^{\mathrm{e}}$ & $16^{\mathrm{a}}$ \\
\hline October & $5.7^{\mathrm{bc}}$ & $1.3^{\mathrm{ab}}$ & $3.6^{\mathrm{ab}}$ & $1.5^{\mathrm{b}}$ & $36.3^{\mathrm{b}}$ & $0.71^{\mathrm{c}}$ & $14^{\mathrm{b}}$ \\
\hline November & $5.5^{\mathrm{c}}$ & $1.2^{\mathrm{bc}}$ & $3.4^{\mathrm{b}}$ & $1.5^{\mathrm{b}}$ & $35.8^{\mathrm{b}}$ & $0.69^{c}$ & $14^{\mathrm{b}}$ \\
\hline SEM & 1.52 & 0.20 & 0.93 & 0.019 & 3.7 & 0.23 & 4.1 \\
\hline Effects & $\mathrm{p}<$ & $\mathrm{p}<$ & $\mathrm{p}<$ & $\mathrm{p}<$ & $\mathrm{p}<$ & $\mathrm{p}<$ & $\mathrm{p}<$ \\
\hline $\mathrm{Y}$ & $*$ & $*$ & $*$ & $*$ & $*$ & $*$ & $*$ \\
\hline $\mathrm{S}$ & $*$ & $*$ & $*$ & $*$ & $*$ & $*$ & $*$ \\
\hline M & $*$ & $*$ & $*$ & $*$ & $*$ & $*$ & $*$ \\
\hline
\end{tabular}


mineral release from forages in the ruminant gastrointestinal tract (Salisbury and Ross, 1994).

\section{In vitro gas production}

The parameters of in vitro gas production are shown in Table 3. No year $\times$ season, year $\times$ month, season $\times$ month and year $\times$ season $\times$ month interactions $(p>0.05)$ were observed for parameters of in vitro gas production. Values of ' $a$ ', ' $b$ ' and 'c' were different between years; the highest values were registered during 2004 ( $\mathrm{p}<0.01)$.

Nevertheless, the values of the lag time were greater in 2005 than in $2004(\mathrm{p}<0.01)$. The gas produced by the soluble fraction (a) and gas produced by the insoluble but slowly fermentable fraction (b), were greater in summer and fall as compared to winter and spring $(\mathrm{p}<0.01)$. The highest gas production rate was obtained in summer $(5.0 \mathrm{ml} / \mathrm{h})$ and the lowest in spring $\left(2.1 \mathrm{~h}^{-1}\right)(\mathrm{p}<0.01)$. The duration of lag time (L) was higher in spring and the lowest in summer $(\mathrm{p}<0.01)$. The highest values of "a", "b" and "c" appeared in August and the lowest in May $(\mathrm{p}<0.05)$. The differences between years and seasons in values of "a", "b" and "c" may be attributed to concentration of soluble carbohydrates in diet selected by grazing cattle (La O et al., 2008).

Table 3. In vitro gas production of the diet consumed by grazing steers

\begin{tabular}{|c|c|c|c|c|}
\hline & A & B & \multirow{2}{*}{$\begin{array}{c}\mathrm{c} \\
\mathrm{ml} / \mathrm{h}\end{array}$} & \multirow{2}{*}{$\begin{array}{l}\mathrm{L} \\
\mathrm{h}\end{array}$} \\
\hline & \multicolumn{2}{|c|}{-------- ml/200 mg DM ------- } & & \\
\hline \multicolumn{5}{|l|}{ Year $(Y)$} \\
\hline 2004 & $4.4^{\mathrm{a}}$ & $99.0^{\mathrm{a}}$ & $3.5^{\mathrm{a}}$ & $2.2^{\mathrm{b}}$ \\
\hline 2005 & $3.2^{\mathrm{b}}$ & $88.1^{\mathrm{b}}$ & $2.6^{\mathrm{b}}$ & $3.4^{\mathrm{a}}$ \\
\hline SEM & 1.2 & 2.4 & 2.2 & 2.0 \\
\hline \multicolumn{5}{|l|}{ Season (S) } \\
\hline Spring & $2.7^{\mathrm{c}}$ & $74.1^{\mathrm{d}}$ & $2.1^{\mathrm{d}}$ & $3.9^{\mathrm{a}}$ \\
\hline Summer & $6.4^{\mathrm{a}}$ & $99.4^{\mathrm{a}}$ & $5.0^{\mathrm{a}}$ & $1.7^{\mathrm{d}}$ \\
\hline Fall & $4.3^{\mathrm{b}}$ & $97.2^{\mathrm{b}}$ & $3.7^{\mathrm{b}}$ & $2.6^{\mathrm{c}}$ \\
\hline Winter & $3.3^{\mathrm{c}}$ & $80.8^{\mathrm{c}}$ & $2.7^{\mathrm{c}}$ & $3.3^{\mathrm{b}}$ \\
\hline SEM & 0.98 & 1.5 & 3.8 & 1.6 \\
\hline \multicolumn{5}{|l|}{ Month (M) } \\
\hline January & $3.4^{\mathrm{c}}$ & $81.6^{\mathrm{c}}$ & $2.8^{\mathrm{cd}}$ & $3.3^{\mathrm{bc}}$ \\
\hline February & $3.3^{\mathrm{c}}$ & $80.1^{\mathrm{c}}$ & $2.6^{\mathrm{de}}$ & $3.4^{\mathrm{b}}$ \\
\hline April & $3.1^{\mathrm{c}}$ & $75.7^{\mathrm{d}}$ & $2.4^{\mathrm{e}}$ & $3.6^{\mathrm{b}}$ \\
\hline May & $2.4^{\mathrm{d}}$ & $72.5^{\mathrm{e}}$ & $1.9^{\mathrm{f}}$ & $4.2^{\mathrm{a}}$ \\
\hline July & $6.2^{\mathrm{a}}$ & $98.2^{\mathrm{b}}$ & $4.9^{\mathrm{ab}}$ & $1.8^{\mathrm{e}}$ \\
\hline August & $6.6^{\mathrm{a}}$ & $102.6^{\mathrm{a}}$ & $5.2^{\mathrm{a}}$ & $1.6^{\mathrm{e}}$ \\
\hline October & $4.6^{\mathrm{b}}$ & $96.6^{\mathrm{b}}$ & $4.2^{\mathrm{b}}$ & $2.9^{\mathrm{cd}}$ \\
\hline November & $4.0^{\mathrm{b}}$ & $96.3^{\mathrm{b}}$ & $3.3^{\mathrm{c}}$ & $2.4^{\mathrm{d}}$ \\
\hline SEM & 0.49 & 2.2 & 3.7 & 1.0 \\
\hline Effects & $\mathrm{p}<$ & $\mathrm{p}<$ & $\mathrm{p}<$ & $\mathrm{p}<$ \\
\hline $\mathrm{Y}$ & $* *$ & $* *$ & $* *$ & $* *$ \\
\hline $\mathrm{S}$ & $* *$ & $* *$ & $* *$ & $* *$ \\
\hline M & $*$ & $*$ & $*$ & $*$ \\
\hline
\end{tabular}

abcdef Means with different superscripts, within column, are different. $\mathrm{SEM}=$ Standard error of mean. $* \mathrm{p}<0.05 ; * * \mathrm{p}<0.01$.
Akinfemi et al. (2009) suggested that gas production from protein fermentation is relatively small as compared to carbohydrate fermentation while the contribution of fat to gas production is negligible. The variations observed between years, seasons and months in the lag time may be explicated by the neutral detergent fiber and lignin content of the diet consumed by grazing cattle, which delay the onset of degradation of nutrients in the rumen (Fievez et al., 2005).

\section{Ruminal fermentation}

The ruminal fermentation patterns are shown in Table 4 . No year $\times$ season, year $\times$ month, season $\times$ month and year $\times$ season $\times$ month interactions were detected $(\mathrm{p}>0.05)$. The $\mathrm{pH}$ value was lower in summer as compared to fall, winter and spring $(\mathrm{p}<0.05)$. The ruminal $\mathrm{NH}_{3} \mathrm{~N}$ concentration was greater in 2004 vs $2005 \quad(\mathrm{p}<0.05)$; while $\mathrm{NH}_{3} \mathrm{~N}$ concentration was higher in summer and fall $(\mathrm{p}<0.01)$. The highest values of $\mathrm{NH}_{3} \mathrm{~N}$ appeared in August and the lowest in May $(p<0.05)$. Other researchers have observed decreases in ruminal $\mathrm{NH}_{3} \mathrm{~N}$ concentrations when diet $\mathrm{CP}$ content decreases with advancing rangelands maturity (Park et al., 1994). The ruminal $\mathrm{NH}_{3} \mathrm{~N}$ concentrations of steers were greater than the $5 \mathrm{mg} / \mathrm{dl}$ concentration suggested for microbial growth and more than the 1 to $2 \mathrm{mg} / \mathrm{dl}$ concentration proposed by Petersen (1987) as necessary for optimal degradation of fiber. The total VFA concentration was affected by years $(\mathrm{p}<0.05)$ and seasons $(\mathrm{p}<0.01)$.

Acetate concentration was greater in 2005 than 2004 $(\mathrm{p}<0.05)$. Acetate concentration did not differ among spring, fall and winter $(p>0.05)$; however, lowest concentration was observed during summer $(\mathrm{p}<0.05)$. The highest acetate concentration was observed in May and the lowest in August $(\mathrm{p}<0.05)$. Acetate is considered to be reflective of cell wall fermentation, and increased acetate levels are normally associated with declining forage quality (Van Soest, 1994). The propionate concentration was affected by years $(\mathrm{p}<0.05)$ and seasons $(\mathrm{p}<0.01)$, with the highest values in 2004 and summer and the lowest in 2005 and other seasons of year. The highest propionate concentration was observed in August and the lowest in May $(\mathrm{p}<0.05)$. Propionate concentration is associated with soluble carbohydrate ruminal fermentation during periods of active rangelands growth (McCollum et al., 1985). Butyrate concentration was greater in 2005 than 2004 ( $\mathrm{p}<0.05)$. Butyrate concentration did not differ between summer and fall ( $p>0.05)$; however, lowest concentration was during summer as compared with other seasons of year $(\mathrm{p}<0.01)$. The highest butyrate concentration was observed in May and the lowest in August ( $\mathrm{p}<0.05)$. McCollum et al. (1985) reported somewhat lower for the butyrate concentration for steers grazing in summer and early August. Similar results to this study with respect to the ruminal fermentation 
Table 4. Ruminal fermentation patterns of the diet consumed by grazing steers

\begin{tabular}{|c|c|c|c|c|c|c|}
\hline & \multirow{2}{*}{$\mathrm{pH}$} & \multirow{2}{*}{$\begin{array}{l}\mathrm{NH}_{3} \mathrm{~N} \\
(\mathrm{mg} / \mathrm{dl})\end{array}$} & \multirow{2}{*}{$\begin{array}{c}\text { VFA } \\
(\mathrm{mM})\end{array}$} & Acetate & Propionate & Butyrate \\
\hline & & & & \multicolumn{3}{|c|}{ 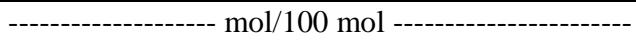 } \\
\hline \multicolumn{7}{|l|}{ Year $(Y)$} \\
\hline 2004 & $6.6^{\mathrm{a}}$ & $12.7^{\mathrm{a}}$ & $69.6^{\mathrm{a}}$ & $63.7^{\mathrm{b}}$ & $15.6^{\mathrm{a}}$ & $6.3^{\mathrm{b}}$ \\
\hline 2005 & $6.8^{\mathrm{a}}$ & $6.3^{\mathrm{b}}$ & $66.2^{\mathrm{b}}$ & $65.2^{\mathrm{a}}$ & $13.4^{\mathrm{b}}$ & $6.6^{\mathrm{a}}$ \\
\hline SEM & 0.11 & 0.53 & 3.6 & 1.6 & 1.1 & 2.4 \\
\hline \multicolumn{7}{|l|}{ Season (S) } \\
\hline Spring & $6.7^{\mathrm{a}}$ & $4.6^{\mathrm{d}}$ & $67.0^{\mathrm{d}}$ & $65.5^{\mathrm{a}}$ & $12.0^{\mathrm{d}}$ & $7.1^{\mathrm{a}}$ \\
\hline Summer & $6.3^{\mathrm{b}}$ & $12.4^{\mathrm{a}}$ & $71.7^{\mathrm{a}}$ & $62.7^{\mathrm{b}}$ & $16.9^{\mathrm{a}}$ & $4.5^{\mathrm{b}}$ \\
\hline Fall & $6.6^{\mathrm{a}}$ & $11.0^{\mathrm{b}}$ & $69.4^{\mathrm{b}}$ & $64.4^{\mathrm{a}}$ & $15.3^{\mathrm{b}}$ & $5.6^{\mathrm{b}}$ \\
\hline Winter & $6.8^{\mathrm{a}}$ & $5.2^{\mathrm{c}}$ & $68.2^{\mathrm{c}}$ & $65.3^{\mathrm{a}}$ & $13.5^{\mathrm{c}}$ & $6.9^{\mathrm{a}}$ \\
\hline SEM & 0.77 & 0.93 & 3.1 & 1.9 & 2.3 & 3.6 \\
\hline \multicolumn{7}{|l|}{ Month (M) } \\
\hline January & $6.9^{\mathrm{a}}$ & $5.3^{\mathrm{d}}$ & $68.8^{\mathrm{cd}}$ & $65.2^{\mathrm{a}}$ & $13.8^{\mathrm{c}}$ & $6.8^{\mathrm{a}}$ \\
\hline February & $6.8^{\mathrm{a}}$ & $5.2^{\mathrm{d}}$ & $67.7^{\mathrm{de}}$ & $65.5^{\mathrm{a}}$ & $13.2^{\mathrm{c}}$ & $7.1^{\mathrm{a}}$ \\
\hline April & $6.7^{\mathrm{a}}$ & $5.1^{\mathrm{d}}$ & $67.2^{\mathrm{de}}$ & $65.3^{\mathrm{a}}$ & $12.4^{\mathrm{d}}$ & $7.0^{\mathrm{a}}$ \\
\hline May & $6.7^{\mathrm{a}}$ & $4.8^{\mathrm{d}}$ & $66.8^{\mathrm{e}}$ & $65.7^{\mathrm{a}}$ & $11.7^{\mathrm{d}}$ & $7.3^{\mathrm{a}}$ \\
\hline July & $6.4^{\mathrm{bc}}$ & $10.6^{\mathrm{c}}$ & $70.8^{\mathrm{b}}$ & $63.2^{\mathrm{b}}$ & $16.7^{\mathrm{a}}$ & $4.6^{\mathrm{b}}$ \\
\hline August & $6.2^{\mathrm{c}}$ & $14.2^{\mathrm{a}}$ & $72.6^{\mathrm{a}}$ & $62.3^{\mathrm{b}}$ & $17 .^{2 \mathrm{a}}$ & $4.4^{\mathrm{b}}$ \\
\hline October & $6.6^{\mathrm{ab}}$ & $12.3^{\mathrm{b}}$ & $69.5^{\mathrm{c}}$ & $64.1^{\mathrm{a}}$ & $15.5^{\mathrm{b}}$ & $5.3^{\mathrm{b}}$ \\
\hline November & $6.6^{\mathrm{ab}}$ & $9.8^{\mathrm{c}}$ & $69.3^{\mathrm{c}}$ & $64.8^{\mathrm{a}}$ & $15.2^{\mathrm{b}}$ & $5.9^{\mathrm{b}}$ \\
\hline SEM & 0.51 & 0.86 & 2.3 & 3.1 & 1.6 & 2.9 \\
\hline Effects & $\mathrm{p}<$ & $\mathrm{p}<$ & $\mathrm{p}<$ & $\mathrm{p}<$ & $\mathrm{p}<$ & $\mathrm{p}<$ \\
\hline $\mathrm{Y}$ & NS & $*$ & $*$ & $*$ & $*$ & $*$ \\
\hline$S$ & $*$ & $* *$ & $* *$ & $*$ & $* *$ & $* *$ \\
\hline M & $*$ & $*$ & $*$ & $*$ & $*$ & $*$ \\
\hline
\end{tabular}

${ }_{\text {abcde }}$ Means with different superscripts, within column, are different. SEM $=$ Standard error of mean. $* \mathrm{p}<0.05 ; * * \mathrm{p}<0.01$.

patterns in grazing cattle were reported by Choat et al. (2003).

\section{In situ ruminal degradability of dry matter}

The parameters of in situ degradability and effective degradability of dry matter are shown in Table 5 . No year $\times$ season, year $\times$ month, season $\times$ month and year $\times$ season $\times$ month interactions ( $p>0.05)$ were observed for ' $a$ ', ' $b$ ', 'c' and 'DMD'. Values of 'a', 'b', 'c', and 'EDDM' were greater in 2004 vs 2005 (p<0.05). The 'a', 'b', 'c', and 'EDDM' values were affected by season of the year $(\mathrm{p}<0.01)$. Under similar conditions to this study, Reyes (2006) found differences between seasons in values of ' $a$ ', 'b', 'c', 'EDDM'. Our highest values of 'a', 'b', 'c', and 'EDDM' appeared in August and the lowest in May $(\mathrm{p}<0.05)$. Average values of 'a' (209 g/kg DM), 'b' (333 $\mathrm{g} / \mathrm{kg} \mathrm{DM})$, 'c' $\left(0.039 \mathrm{~h}^{-1}\right)$ and 'EDMD' (401 g/kg DM) reported by Ramírez et al. (2001) in nine grasslands in northeastern Mexico are lower than those obtained in this study for the month of August. Also, Obeidat et al. (2002) reported lower values of ' $b$ ' for the months of February (482 g) and May (398 g) than our findings. Ramírez et al. (2004) suggested that weather conditions are the cause of these differences, since temperature and rainfall have a direct effect on degradability of dry matter in grasslands of northern Mexico.

\section{In situ ruminal degradability of neutral detergent fiber}

The parameters of in situ degradability and effective degradability of neutral detergent fiber are shown in Table 6. No year $\times$ season, year $\times$ month, season $\times$ month and year $\times$ season $\times$ month interactions ( $p>0.05)$ were observed for ' $a$ ', 'b', 'c' and 'EDNDF'. Losses of NDF due to washing (fraction A), degradable fraction (B), rate of degradation (c), as well as EDNDF were different between years $(p<0.05)$. Small portions of NDF that were partitioned in fraction A could be associated, in part, with losses of small particles of the diet through pores in the bags more than with solubilization of components of the cell wall (Ogden et al., 2005). Values of 'A', 'B', 'c', and 'EDNDF' were different between seasons $(\mathrm{p}<0.01)$. Under conditions similar to those of our study. Fredrickson et al. (1993) reported higher NDF degradability parameters in summer compared to spring. Constant NDF degradation rates were faster in summer $\left(0.037 \mathrm{~h}^{-1}\right)$ and fall $\left(0.031 \mathrm{~h}^{-1}\right)$ compared to winter $\left(0.025 \mathrm{~h}^{-1}\right)$ and spring $\left(0.019 \mathrm{~h}^{-1}\right)$, but all were lower than rates reported by Funk et al. (1987; $\left.0.042 \mathrm{~h}^{-1}\right)$. However, values for rate of degradation of NDF obtained by Caton et 
Table 5. In situ degradability and effective degradability of dry matter of the diet consumed by grazing steers

\begin{tabular}{|c|c|c|c|c|}
\hline & $\mathrm{a}$ & B & \multirow{2}{*}{$\begin{array}{c}\mathrm{c} \\
\mathrm{h}^{-1}\end{array}$} & \multirow{2}{*}{$\begin{array}{l}\text { EDDM } \\
\text { g/kg DM }\end{array}$} \\
\hline & \multicolumn{2}{|c|}{------- g/kg DM ------- } & & \\
\hline \multicolumn{5}{|l|}{ Year (Y) } \\
\hline 2004 & $207.0^{\mathrm{a}}$ & $625.0^{\mathrm{a}}$ & $0.041^{\mathrm{a}}$ & $602.0^{\mathrm{a}}$ \\
\hline 2005 & $182.0^{\mathrm{b}}$ & $595.0^{\mathrm{b}}$ & $0.023^{\mathrm{b}}$ & $568.0^{\mathrm{b}}$ \\
\hline SEM & 1.6 & 2.1 & 0.051 & 3.4 \\
\hline \multicolumn{5}{|l|}{ Season $(\mathrm{S})$} \\
\hline Spring & $181.7^{\mathrm{d}}$ & $581.0^{\mathrm{d}}$ & $0.023^{\mathrm{d}}$ & $497.4^{\mathrm{d}}$ \\
\hline Summer & $269.5^{\mathrm{a}}$ & $642.8^{\mathrm{a}}$ & $0.069^{\mathrm{a}}$ & $614.1^{\mathrm{a}}$ \\
\hline Fall & $210.4^{\mathrm{b}}$ & $623.2^{\mathrm{b}}$ & $0.052^{\mathrm{b}}$ & $602.6^{\mathrm{b}}$ \\
\hline Winter & $194.2^{\mathrm{c}}$ & $589.7^{\mathrm{c}}$ & $0.030^{\mathrm{c}}$ & $525.4^{\mathrm{c}}$ \\
\hline SEM & 2.8 . & 1.2 & 0.012 & 1.6 \\
\hline \multicolumn{5}{|l|}{ Month (M) } \\
\hline January & $196.1^{\mathrm{d}}$ & $595.3^{\mathrm{e}}$ & $0.032^{\mathrm{c}}$ & $526.2^{\mathrm{e}}$ \\
\hline February & $192.3^{\mathrm{e}}$ & $584.2^{\mathrm{f}}$ & $0.028^{\mathrm{d}}$ & $524.7^{\mathrm{e}}$ \\
\hline April & $188.3^{\mathrm{f}}$ & $582.1^{\mathrm{g}}$ & $0.025^{\mathrm{e}}$ & $507.0^{\mathrm{f}}$ \\
\hline May & $175.2^{\mathrm{g}}$ & $580.0^{\mathrm{g}}$ & $0.022^{\mathrm{f}}$ & $487.8^{\mathrm{g}}$ \\
\hline July & $256.4^{\mathrm{b}}$ & $638.1^{\mathrm{b}}$ & $0.068^{\mathrm{a}}$ & $612.6^{\mathrm{b}}$ \\
\hline August & $282.7^{\mathrm{a}}$ & $647.6^{\mathrm{a}}$ & $0.070^{\mathrm{a}}$ & $615.7^{\mathrm{a}}$ \\
\hline October & $211.3^{\mathrm{c}}$ & $626.8^{c}$ & $0.053^{\mathrm{b}}$ & $608.0^{c}$ \\
\hline November & $209.6^{\mathrm{c}}$ & $619.7^{\mathrm{d}}$ & $0.051^{\mathrm{b}}$ & $597.3^{\mathrm{d}}$ \\
\hline SEM & 3.1 & 1.5 & 0.021 & 2.7 \\
\hline Effects & $\mathrm{p}<$ & $\mathrm{p}<$ & $\mathrm{p}<$ & $\mathrm{p}<$ \\
\hline $\mathrm{Y}$ & $*$ & $*$ & $*$ & $*$ \\
\hline S & $* *$ & $* *$ & $* *$ & $* *$ \\
\hline M & $*$ & $*$ & $*$ & $*$ \\
\hline
\end{tabular}

al. (1988) $\left(0.031 \mathrm{~h}^{-1}\right)$ and Barton et al. (1992) $\left(0.022 \mathrm{~h}^{-1}\right)$ are similar to our findings for spring, fall and winter.

Values of the parameters (A, B, c, and EDNDF) were greater in August vs May ( $p<0.05)$. Gelvin et al. (2004) reported lower values for NDF degradation rate in August and October $\left(0.019 \mathrm{~h}^{-1}\right.$ and $0.011 \mathrm{~h}^{-1}$, respectively). The differences observed between years and seasons in the parameters of NDF may be a result of different lignin content in the diet consumed by cattle (Juárez et al., 2004).

\section{CONCLUSIONS}

This study showed that drought induced by season results in a decrement of the nutritive quality of the diet because of the decreasing $\mathrm{CP}$ and increasing of NDF contents. These changes are accompanied by decreases in the mineral content, in situ degradability, in vitro gas production and ruminal fermentation of diet grazing cattle. Protein and energy supplementation might $b>$ beneficial for cattle grazing during spring and winter. The Se content
Table 6. In situ degradability and effective degradability of neutral detergent fiber of the diet consumed by grazing steers

\begin{tabular}{|c|c|c|c|c|}
\hline & A & B & \multirow{2}{*}{$\begin{array}{c}\mathrm{C} \\
\mathrm{h}^{-1}\end{array}$} & \multirow{2}{*}{$\begin{array}{l}\text { EDNDF } \\
\text { g/kg NDF }\end{array}$} \\
\hline & \multicolumn{2}{|c|}{-------- g/kg NDF------- } & & \\
\hline \multicolumn{5}{|l|}{ Year (Y) } \\
\hline 2004 & $86.6^{\mathrm{a}}$ & $424.0^{\mathrm{a}}$ & $0.027^{\mathrm{a}}$ & $334.5^{\mathrm{a}}$ \\
\hline 2005 & $44.7^{\mathrm{b}}$ & $386.5^{\mathrm{b}}$ & $0.023^{\mathrm{b}}$ & $266.6^{\mathrm{b}}$ \\
\hline SEM & 1.3 & 2.1 & 0.018 & 2.2 \\
\hline \multicolumn{5}{|l|}{ Season $(\mathrm{S})$} \\
\hline Spring & $28.6^{\mathrm{d}}$ & $369.8^{\mathrm{d}}$ & $0.019^{\mathrm{d}}$ & $253.4^{\mathrm{d}}$ \\
\hline Summer & $96.2^{\mathrm{a}}$ & $503.7^{\mathrm{a}}$ & $0.037^{\mathrm{a}}$ & $357.7^{\mathrm{a}}$ \\
\hline Fall & $77.5^{\mathrm{b}}$ & $469.9^{b}$ & $0.031^{\mathrm{b}}$ & $342.7^{\mathrm{b}}$ \\
\hline Winter & $35.0^{\mathrm{c}}$ & $390.3^{c}$ & $0.025^{\mathrm{c}}$ & $340.4^{c}$ \\
\hline SEM & 2.3 & 3.1 & 0.022 & 3.4 \\
\hline \multicolumn{5}{|l|}{ Month (M) } \\
\hline January & $35.8^{\mathrm{e}}$ & $398.0^{\mathrm{e}}$ & $0.027^{\mathrm{e}}$ & $273.5^{\mathrm{e}}$ \\
\hline February & $34.2^{\mathrm{e}}$ & $382.6^{\mathrm{f}}$ & $0.024^{\mathrm{f}}$ & $270.6^{\mathrm{f}}$ \\
\hline April & $31.5^{\mathrm{f}}$ & $372.3^{\mathrm{g}}$ & $0.021^{\mathrm{g}}$ & $263.2^{\mathrm{g}}$ \\
\hline May & $25.7^{\mathrm{g}}$ & $367.4^{\mathrm{h}}$ & $0.017^{\mathrm{h}}$ & $243.6^{\mathrm{h}}$ \\
\hline July & $87.3^{\mathrm{b}}$ & $498.3^{b}$ & $0.036^{\mathrm{b}}$ & $346.3^{\mathrm{b}}$ \\
\hline August & $105.2^{\mathrm{a}}$ & $509.2^{\mathrm{a}}$ & $0.038^{\mathrm{a}}$ & $369.2^{\mathrm{a}}$ \\
\hline October & $78.7^{\mathrm{c}}$ & $471.2^{\mathrm{c}}$ & $0.032^{\mathrm{c}}$ & $341.8^{\mathrm{c}}$ \\
\hline November & $76.3^{d}$ & $468.6^{\mathrm{d}}$ & $0.030^{\mathrm{d}}$ & $339.1^{\mathrm{d}}$ \\
\hline SEM & 1.1 & 1.6 & 0.016 & 2.8 \\
\hline Effects & $\mathrm{p}<$ & $\mathrm{p}<$ & $\mathrm{p}<$ & $\mathrm{p}<$ \\
\hline $\mathrm{Y}$ & $*$ & $*$ & $*$ & $*$ \\
\hline $\mathrm{S}$ & $* *$ & $* *$ & $* *$ & $* *$ \\
\hline $\mathrm{M}$ & $*$ & $*$ & $*$ & $*$ \\
\hline
\end{tabular}

abcdefgh Means with different superscripts, within column, are different SEM $=$ Standard error of mean. $* \mathrm{p}<0.05 ; * * \mathrm{p}<0.01$.

EDNDF was estimated with the following $\mathrm{kp}$ obtained in this study: January, $0.015 \mathrm{~h}^{-1}$; February, $0.018 \mathrm{~h}^{-1}$; April, $0.014 \mathrm{~h}^{-1}$; May, $0.03 \mathrm{~h}^{-1}$; July, $0.026 \mathrm{~h}^{-1}$; August, $0.034 \mathrm{~h}^{-1}$; October, $0.028 \mathrm{~h}^{-1}$; November, $0.02 \mathrm{~h}^{-1}$.

increases with maturity of rangelands plants. With the exception of Se, in the summer the mineral content was higher, compared to fall, spring and winter. $\mathrm{Ca}, \mathrm{Mg}, \mathrm{Na}, \mathrm{Zn}$, $\mathrm{Se}$, and $\mathrm{Cu}$ supplied by the diet, meet the requirements of grazing native rangelands cattle; while $\mathrm{P}$ content was deficient in both years and seasons. Our study provides new knowledge which can be used to make more precise the formulation of supplements that grazing cattle need to improve their productive and reproductive performance. Our study also provides new knowledge on the NDF fraction in the diet of grazing steers regarding the loss of particulates due to bag washing. This fraction is associated with high contents of lignocellulosic matter, which makes it a good indicator of nutritive quality of the diet selected by grazing cattle.

\section{ACKNOWLEDGEMENTS}

We thank the CONACYT-State Government of Durango Mixed Fund (FOMIX-DGO; Project: DGO-2002-CO1- 
2522) for funding our investigation and the collaboration of the academic groups: Sustainable Production of Beef and Dairy Cattle (FMVZ-UJED) and Animal Nutrition (FZyE$\mathrm{UACh}$ ) is also recognized

\section{REFERENCES}

Akinfemi, A., A. O. Adesanya and V. E. Aya. 2009. Use of an in vitro gas production technique to evaluate some Nigerian feedstuff. Am. Eur. J. Sci. Res. 4:240-245.

AOAC. 1997. Official methods of analysis of the AOAC. 16th edn. Association of Official Agricultural Chemists Arlington: AOAC International, Washington, USA.

Arthington, J. D. and C. K. Swenson. 2004. Effects of trace mineral source and feeding method on the productivity of grazing Braford cows. Prof. Anim. Sci. 20:155-161.

Barton, P. K., L. J. Krysl, M. B. Judkins, D. W. Holcombe, J. T. Broesder, S. A. Gunter and S. W. Beam. 1992. Time of daily supplementation for steers grazing dormant intermediate wheatgrass pasture. J. Anim. Sci. 70:547-558.

Caton, J. S., A. S. Freeman and M. L. Galyean. 1988. Influence of protein supplementation on forage intake, in situ forage disappearance, ruminal fermentation and digesta passage rates in steers grazing dormant blue grama rangeland. J. Anim. Sci. 66:2262-2271.

Chávez, S. A. H and F. González. 2009. Estudios Zootécnicos (Animales en Pastoreo). In: Rancho Experimental la Campana, 50 años de Investigación y Transferencia de Tecnología en Pastizales y Producción Animal (Ed. S. A. H. Chávez). Instituto Nacional de Investigaciones Forestales, Agrícolas y Pecuarias. pp. 113-206.

Cherney, D. J. R. 2000. Characterization of forages by chemical analysis. In: Forage Evaluation in Ruminant Nutrition (Ed. D. I. Givens, E Owen, R. F. E Axford and H. M. Omed). Wallingford. CAB Publishing. pp. 275-300.

Choat, W. T., C. R. Krehbiel, G. C. Duff, R. E. Kirksey, L. M. Lauriault and J. D. Rivera. 2003. Influence of grazing dormant native range or winter pasture on subsequent finishing cattle performance, carcass characteristics and ruminal metabolism. J. Anim. Sci. 81:3191-3201.

Cline, H. J., B. W. Neville, G. P. Lardy and J. S. Caton. 2009. Influence of advancing season on dietary composition, intake, site of digestion and microbial efficiency in beef steers grazing a native range in western North Dakota. J. Anim. Sci. 87:375383.

Fievez, V., O. J. Babayemi and D. Demeyer. 2005. Estimation of direct and indirect gas production in syringes: A tool to estimate short chain fatty acid production that requires minimal laboratory facilities. Anim. Feed Sci. Technol. 123124:197-210.

Fredrickson, E. L., M. L. Galyean, M. E. Branine, B. Sowell and J. D. Wallace. 1993. Influence of ruminally dispensed monensin and forage maturity on intake and digestion. J. Range Manage. 46:214-220

Funk, M. A., M. L. Galyean, M. E. Branine and L. J. Krysl. 1987. Steers grazing blue grama rangeland and throughout the growing season. I. Dietary composition, intake, digesta kinetic and ruminal fermentation. J. Anim. Sci. 65:1342-1348.
Galyean, M. L. 1997. Laboratory procedures in animal nutrition research. Texas Tech University, 77 pp. Available from www.app.depts.ttu.edu (accessed Feb 17, 2006).

Gelvin, A. A., G. P. Lardy, S. A. Soto-Navarro, D. G. Landblom and J. S. Caton. 2004. Effect of field pea-based creep feed on intake, digestibility, ruminal fermentation and performance by nursing calves grazing native range in western North Dakota. J. Anim. Sci. 82:3589-3599.

González, R. H., O. F. Carrete and O. F. Meraz, F. 2007. Cadena Agroalimentaria Bovinos Carne en Durango: Diagnostico y Perspectivas. SAGARPA-INIFAP. Publicación Técnica $n^{\circ} 2$, 22-35.

Haenlein, G. J. W. and R. G. Ramirez. 2007. Potential mineral deficiencies on arid rangelands for small ruminants with special reference to Mexico. Small Rumin. Res. 68:35-41.

Holechek, J. L., M. Vavra and R. D. Pieper. 1982. Methods for determining the nutritive quality of range management diets: a review. J. Anim. Sci. 54:353-362.

Jančíc, F., V. Koukolová and P. Homolka. 2010. Ruminal degradadability of dry matter and neutral detergent fibre of grasses. Czech. J. Anim. Sci. 55:359-371.

Juárez, A. S., R. Montoya, G. Nevarez, M. A. Cerrillo and F. L. Mould. 2004. In situ degradability of dry matter and neutral detergent fiber of thorn scrubland forage consumed by goats in the semi-arid region of northern Mexico. Anim. Sci. 79:505511.

Khazaal, K., M. T. Dentinho, J. M. Ribeiro and E. R. Orskov. 1995 Prediction of apparent digestibility and voluntary intake of hay fed to sheep: comparison between characteristics of gas production or nylon bag degradation. Anim. Sci. 61:527-538.

La O., O., R. García, O. Ruiz, Y. Castillo, A. Muro, C. Rodríguez, C. Arzola, H. González and B. Ortiz. 2008. Potencial fermentativo ruminal in vitro de dos árboles (Pithecellobium dulce y Tamarindos indica) de importancia para la ganadería en ecosistemas frágiles, salinos y de alta sequia, situados en el Oriente de Cuba. Nota Técnica. Rev. Cub. Cien. Agrí. 42:5760.

Litell, R. C., P. R. Henry and C. B. Ammerman. 1998. Statistical analysis of repeated measures data using SAS procedures. J. Anim. Sci. 76:1216-1231.

McCollum, F. T., M. L. Galyean, L. J. Krysl and J. D. Wallace. 1985. Cattle grazing blue grama rangeland. I. Seasonal diets and rumen fermentation. J. Range. Manage. 38:539-542.

McDonald, J. 1981. A revised model for the estimation of protein degradability in the rumen. J. Agric. Sci. 96:251-252.

McDowell, L. R. 1992. Mineral in animal and human. Academic Press INC, USA.

McDowell, L. R. 2003. Mineral in animal and human. 2nd Ed. Elsevier, The Netherlands,

Menke, K. H. and H. Steingass. 1988. Estimation of the energetic feed value obtained from chemical analysis and in vitro gas production using rumen fluid. Anim. Res. Develop. 28:7-55.

Murillo, O. M., O. F. Carrete and O. Ruiz. 2003. Mathematical models comparison to determine the in situ dry matter degradability of five forages. In: Proceedings of the Sixt International Symposium on the Nutrition Herbivores. Merida, Yucatan, Mexico. pp. 295-299.

Njidda, A. A. and A. Nasiru. 2010. In vitro gas production and dry matter digestibility of tannin-containing forages of semi-arid 
region of north- eastern Nigeria. Pak. J. Nutr. 9:60-66.

National Research Council. 2000. Nutrient requirements of beef cattle. 7th ed, Washington: National Academic Press, pp. 246.

Obeidat, B. S., M. G. Thomas, D. M. Hallford, D. H. Keisler, W. D. Petersen, W. D. Bryant, M. D. García, L. Narro and R. Lopez. 2002. Metabolic characteristics of multiparous Angus and Brahman cows grazing in the Chihuahua Desert. J. Anim. Sci. 80:2223-2233.

Ogden, R. K., W. K. Coblentz, K. P. Coffey, J. E. Turner, D. A. Scarbrough, J. A. Jennings and M. D. Richardson. 2005. Ruminal in situ disappearance kinetics of dry matter and fiber in growing steers for common crabgrass forages sampled on seven dates in northern Arkansas. J. Anim. Sci. 83:1142-1152.

Orskov, E. R. and W. J. Shand. 1997. Use of the nylon bag technique for protein and energy evaluation and for rumen environment studies in ruminants. Lives. Res. Rural. Develop. 9:1-10.

Park, K. K., L. J. Krysl, B. A. McCracken, M. B. Judkins and W. Holcombe. 1994. Steers grazing intermediate wheatgrass at various stages of maturity: Effects on nutrient quality, forage intake, digesta kinetics, ruminal fermentation, and serum hormones and metabolites. J. Anim. Sci. 72:478-486.

Petersen, M. K. 1987. Nitrogen supplementation of grazing livestock. In: in Proceedings. Grazing Livestock. University of Wyoming. pp. 115-122.
Ramírez, R. G., M. E. Enríquez and G. F. Lozano. 2001. Valor nutricional y degradabilidad ruminal de zacate buffel y nueve zacates nativos del NE de México. Ciencia UANL, 4:314-321.

Ramírez, R. G., G. F. Haenlein, C. C. Garcia and G. M. Nuñez. 2004. Protein, lignin and mineral contents and in situ dry matter digestibility of native Mexican grasses consumed by range goats. Small Rumin. Res. 52:261-269.

Reyes, E. O., M. Murillo, E. Herrera, M. Guerrero, G. Nevarez, R. Montoya, M. A. Cerrillo and A. S. Juárez. 2006. In situ dry matter degradation kinetics of the diet selected by grazing cattle in a grassland of Northern Mexico. Annual Meeting. ADSA-ASAS, Minneapolis, USA. pp. 1-742.

Salisbury, F. B. and C. W. Ross. 1994. Absorción de sales minerales. In: Fisiologia Vegetal. Grupo Editorial Iberoamericana. pp. 122-136.

SAS Institute Inc. 2003. SAS/STAT User's Guide: Release 9.1. SAS Institute, Cary, North Caroline, USA.

Van Soest, P. J. 1994. Nutritional ecology of the ruminant. 2th Ed. New York, Cornell Univesity Press, USA.

Van Soest, P. J., J. B. Robertson and B. A. Lewis. 1991. Methods for dietary fiber, neutral detergent fiber, and non-starch polysaccharides in relation to animal nutrition. J. Dairy Sci. 74:3583-3597.

Waterman, R. C., E. E. Grings, T. W. Geary, A. L. Roberts, L. J. Alexander and M. D. MacNeil. 2007. Influence of seasonal forage quality on glucose kinetics of young beef cows. J. Anim. Sci. 85:2582-2595. 